\title{
A Narrative Study of Science Teaching Methods and Techniques in the New Normal
}

\author{
Jastine Kent Florungco ${ }^{*}$ - https://orcid.org/0000-0001-5103-7848, Dennis G. Caballes ${ }^{2}$ \\ ${ }^{1}$ Centro Escolar University, Philippines, ${ }^{2}$ De La Salle-College of St. Benilde, Philippines \\ *e-mail: 1*florungco2001423@ceu.edu.ph,2ㄹennis.caballes@benilde.edu.ph
}

\begin{tabular}{l}
\hline \multicolumn{1}{c}{ Article Information } \\
\hline Received: April 30, 2021 \\
Revised: June 05, 2021 \\
Accepted: June 05, 2021 \\
Online: August 09, 2021 \\
\multicolumn{1}{c}{ Keywords } \\
\hline $\begin{array}{l}\text { techniques, methods, competencies, } \\
\text { assessments }\end{array}$
\end{tabular}

assessments

\begin{abstract}
This study aims to discover the different techniques teachers use in delivering lessons in an online class. Teachers are still adjusting to the effects of the pandemic on the education system, particularly on the delivery of learning online. It was revealed that educators tend to test various techniques in teaching the learners' competencies. Assessments play a key role in dictating the success of these methods, which is why teachers are seemed to be very cautious in conducting quizzes and exams because these may be prone to cheating since it is online nature. On the other hand, the ongoing internet issues still hound the system here in the country.
\end{abstract}

\section{INTRODUCTION}

As the world continues to battle with the pandemic brought about by COVID-19, every sector is finding its way to adapt to the new normal. Educators are adjusting to the new ways in how they deliver their lessons and conduct assessments for the benefit of the learners. A report by Tobias (2021) mentioned that teachers in the Philippines are still in the phase of adjustment in working through online learning, noting that students' behavior, connectivity issues, and other technical malfunction may hinder the proper conveyance of learnings. Manila Standard Lifestyle (2020) indicated that teachers have not gotten over the difficulties due to the abrupt changes in the education system, with most of them leaning towards learning technological skills to cope with the needs of the online modality. In addition, teachers have problems with the transition of materials from traditional to digital teaching. These are complicated by the need to make these lessons interesting and functional for the learners.

Gamiao (2020) stressed that teachers' traditional chalk and talk method is not necessarily applicable in the online setting because the students have a short attention span due to online games and other gadgets. It is also an essential duty of an educator to aid the students in the learning process. Several educators have shared their insights about pedagogy and how to deliver an online class on a reasonable method. Latheef (2020) explained that to optimize a proper synchronous class, teachers must have a well-thought strategy which should be a student-centered learning session. He noted that the short attention span of the learners would be addressed by engaging them directly in the discussion proper. The objective and goal of the learning session should also be clarified to set the learners' expectations. In addition, interactions between students and teachers must be built to ensure that the activities are done with camaraderie. Teachthought (n.d.) emphasized the importance of letting the students experience what they learned using laboratories online. These will serve as supplements for the students to get knowledge during online sessions. It is backed up by an article by Angelo State University, which elaborated that learners should focus and explore the content to stimulate learning. May and Elkana (2020) added that an important step in ensuring a productive online session is giving simple and direct instructions that the learners can easily follow.

The University of Illinois in Springfield stated that educators must apply strategies to help achieve the session's goals and objectives. This research aims to describe the teaching methods utilized by 
secondary Science teachers in their online sessions. This study aims to find out the effectiveness of teaching techniques teachers are employing in the new normal. Specifically, the research aims to complete the following research objectives:

1. To determine the most common and effective methods and techniques educators used in teaching Science online;

2. To understand the factors that need to be considered to clearly show that a teaching method being implemented is effective for distance learning;

3. To identify challenges are being faced by teachers in the delivery of the lessons in an online class; and

4. To know vital roles do the teachers play in education in the new normal.

\section{Literature review}

The researcher found that a limited number of works and studies tackle effective teaching strategies in teaching Science online.

\section{Teaching methods in an online class}

As the shift to online modality is inevitable due to the current situation, it should be kept in mind that the content and delivery method should be planned and selected thoroughly. Miller (2008), in his study, stated that letting the educators have their learning adventures can be advantageous since they must grasp further the concepts being studied in Science. In addition, he also pitched that teachers also pick up knowledge by doing activities that they are teaching. The pedagogical aspect should focus more on the students' skills development, which encourages them to participate actively in the discussion (Harvard University, nd). Bybee, Taylor, Gardner, and Scotter (2006) emphasized the importance of the 5E model (Engage, Exploration, Explanation, Elaboration, \& Evaluation) in teachers' instructional point of view. They noted that proper utilization of this model does not only aid the teachers in forming meaningful material, but it also helps the students learn basic concepts in the field of Science. Another aspect that needs to be looked upon is the integration of technology in the teaching process. Redmond (2011) noted that teachers in an online class exert time and effort to learn and utilize the technological materials necessary to deliver lessons. Yang (2013) mentioned that some of the most used strategies in online Science teaching include letting the students interact in the learning activities, promoting the application of problem-based learning to highlight the concepts being tackled, utilization of video presentations, and making the learners feel they belong to a community that has a harmonious relationship. An integral part of learning Science, even in distance learning, is integrating experiments to substantiate the ideas embedded in the lesson. He also acknowledged the importance of communication in a learning community, whether in real-time via the media platforms available or when the students feel comfortable on their schedules. According to the same study, these sessions play a vital role in addressing the students' learning process problems. Babincakova and Bernard (2020), citing the work of Kang and Wallace, stressed the vital role of experimentation in teaching Science. They also noted that these activities could be integrated by providing instructional materials with photographs or demonstrating the activities in real-time or recorded.

\section{Challenges encountered by the teachers}

Along with these changes are challenges that these educators face. Konig, Bielan, and Glutsch (2020) published a study stating that several problems are experienced in this learning modality. One of which is how learners can cope with the lesson, including the materials used in the class session. In addition, the reliability of assessment being given after the learning session is also of great concern for the educators. It is being highlighted when most students are not present in class. It is acknowledged in the published work of Yang (2004), saying that cheating on the students' part is of high possibility. In their published work, Arrieta, Dancel, and Agbisit (2020) acknowledged the high possibility of cheating and academic dishonesty in this type of learning scenario.

Yang (2004) noted that role change on the part of the teachers could also be considered a barrier. Miller (2008) stated that teachers need to have a definite course of action in executing the learning session, which is easier said than done. Another facet that teachers need to address is the manner they 
present themselves online. Yang and Cornelius (2005) mentioned that educators must control their behavior while teaching online. They also mentioned in their study the idea of attaining and maintaining high standards in an online class.

These challenges involve change which requires educators to adapt to the current situation. Miller (2008) noted that engaging in a distance learning activity also involves changing the teachers' psychological perspective. Redmond (2011) acknowledges the anxiety teachers feel when facing an unchartered territory in teaching. He cited Meloncon's (2007) work, saying that teachers must think of new strategies to adapt to the change. Yang (2004) pointed out that educators' role in the learning activity is relegated to just being a guide for the learners. In essence, students are the central figure in this setup. It is supported by the study of Yang and Cornelius (2005), stating that, with online education focusing more on the learners, teachers are often in charge of facilitating the learning activities inside the class. It highlights one of the many comparisons between traditional and online learning. Lastly, Yang also mentioned that building a community with the learners also poses a daunting challenge for the teachers. It serves as an additional workload for teachers, especially those used to handling students personally.

Oyelekan, Igbokwe, \& Olorundare (2017) state that teachers who show mastery in online learning strategy in Science teaching have students who showed improvement in academic performance scores compared to those taught using a traditional method.

\section{METHODS}

\section{Research design}

This research employed a narrative research design and qualitative method to reach this study's objectives: To assess the effects of the teaching methods they are employing in the execution of an online class. The researcher made use of the interview method as the main source for the data collection. This research also aims to explore the challenges educators are experiencing in the modality above. The roles of the teachers in online classes were tackled.

\section{Sample}

The intended respondents of this study are secondary Science teachers of a Private school in the Philippines who are involved in an online class modality. The research utilized 12 respondents for this study, which fall under the scope above and category.

\section{Sampling technique}

The respondents were selected using purposive sampling because secondary Science teachers affiliated with an educational institution employing online classes are the intended informants for this study.

\section{Data Collection and Data Analysis techniques}

The interview is unstructured was done in an unstructured manner. In this way, the interviewees were given the liberty to express their answers comfortably. Questions were distributed with the aid of Google forms. The respondents were given code names, and the data gathered through the interview were encoded, analyzed, and interpreted using thematic analysis. Prieto, Naval, \& Carey (2017) defined thematic analysis as pattern recognition within the data. The researchers adhere to the right to the confidentiality of the respondents. A letter of interview request was sent to the institution before conducting the data collection procedure, and the respondents were informed that they could withdraw anytime if deemed uncomfortable with the situation. All the data gathered will be treated confidentially and used for the sole purpose of this study.

\section{RESULTS AND DISCUSSION}

This part of the study shows the data gathered by the researcher. The data gathered were organized, presented, analyzed, and interpreted by the researcher to formulate a well-thought conclusion. 


\section{Part 1. Description of teaching techniques employed by teachers}

The first part of the online interview asked the respondent teachers about the teaching techniques and methods in the new normal of education during these online classes. The majority of the respondents revealed that they are using varying methods in conducting their lessons. These methods range from having an interactive session, using games as part of the discussion, and having an inquirybased approach. A study by Pokhrel and Chhetri (2021) emphasized the need for both the teachers and students to maximize the different resources that can help achieve teaching in online classes. Here are the responses of the informants:

Table 1. The Responses of the Informants when Description of Teaching Techniques

\begin{tabular}{ll}
\hline Informant 1 & I would say I use different strategies to achieve interactive and \\
cooperative learning for my students. I use different technological \\
tools and interactive games
\end{tabular}

\section{Part 2. Parameters that gauge the success of online classes}

This part tackles the factors being looked into to say that an online learning session achieves its goals and objectives. Most of the respondents acknowledged the vital role of assessments in dictating the direction of the online learning session. It implies that teachers mostly rely on the results of the quizzes and exams to know and measure the learning and understanding of students about a certain topic. Swan, Shen, and Hiltz (2008) noted the conducting assessment in an online learning session could be a challenging task since every technique should be reconsidered to ensure the validity of the exam. Here are the responses of the informants:

Table 2. Parameters that gauge the success of online classes

Informant 1
If students are continuously responding to my questions during discussion, they are also interacting, sharing their thoughts, and asking for clarifications 


\begin{tabular}{|c|c|}
\hline Informant 2 & $\begin{array}{l}\text { By asking them a specific question can derive the definition or the } \\
\text { concept of the lesson by giving them some exercises and quizzes so } \\
\text { that I can know if I met my expectation of my students }\end{array}$ \\
\hline Informant 3 & $\begin{array}{l}\text { Well, for this one, I cannot tell because almost everything can be } \\
\text { found on the internet, which hardly tells whether we are effective or } \\
\text { not, but we could use the exam, quizzes, and even perform tasks and } \\
\text { activities to tell the competencies that were met. These assessment } \\
\text { data about how the students are performing will help us identify if } \\
\text { lessons are delivered efficiently and effectively }\end{array}$ \\
\hline Informant 4 & $\begin{array}{l}\text { Checking the alignment of MELCS and Modules. Then the output of } \\
\text { the students in their integrative assessment }\end{array}$ \\
\hline Informant 5 & Aligning my lessons to the learning competencies in MELCS \\
\hline Informant 6 & $\begin{array}{l}\text { Aside from the quizzes, long tests, and unit test the students answer } \\
\text { per quarter, I give pre-test and post-test questions during } \\
\text { synchronous sessions to know whether they understood our past and } \\
\text { current lessons }\end{array}$ \\
\hline Informant 7 & $\begin{array}{l}\text { *Students participate during the discussion (giving feedback or } \\
\text { asking questions) *If at least } 75 \% \text { of the class have a high score in } \\
\text { their activities or task *if students can demonstrate skills or } \\
\text { understanding about the specific topic *Students enjoy and have fun } \\
\text { during the session. }\end{array}$ \\
\hline Informant 8 & $\begin{array}{l}\text { Giving proper assessment instruments gives a proper assessment of } \\
\text { the students' performance. }\end{array}$ \\
\hline Informant 9 & Student evaluation and teacher evaluation \\
\hline Informant 10 & The students are almost able to deliver acceptable responses. \\
\hline Informant 11 & $\begin{array}{l}\text { Whenever I give assessments to students, and they can get a high } \\
\text { score. I think I am effective in delivering the lessons to them }\end{array}$ \\
\hline
\end{tabular}

Part 3: Challenges encountered that accompanies the teaching method being employed

This part focuses on the obstacles encountered by the teachers that come along with the teaching techniques they are employing. The respondents are unanimous in stating that all of them are being hindered by the slow internet connection being offered. Lagua (2020) noted that teachers should be prepared for a highly likely cause of an internet connectivity issue since this issue is always an imminent one.

Table 3. Challenges encountered that accompanies the teaching method being employed

\begin{tabular}{ll}
\hline Informant 1 & The problem in internet connection, difficulty in focusing on the \\
& lessons because of some distractions at home \\
\hline Informant 2 & $\begin{array}{l}\text { First, Internet connectivity. Second, those students who have no } \\
\text { laptop or any gadget can be used for their study. Lastly, my } \\
\text { PowerPoint presentation for graphing is so hard because I need more } \\
\text { time to do that. }\end{array}$ \\
\hline Informant 3 & $\begin{array}{l}\text { Since we are dealing virtually, internet connection is one of the major } \\
\text { concerns here. Having a poor connection, intermittent connection } \\
\text { affects online classes }\end{array}$ \\
\hline Informant 4 & Internet connectivity, a device used by the students, knowledge in \\
& using LMS \\
\hline Informant 5 & Weak or loss of Internet connection of the learners \\
\hline Informant 6 & Unstable internet connection is the main challenge that my students \\
and I face the most. Also, it is a challenge that I do not get to interact
\end{tabular}




\begin{tabular}{ll}
\hline & $\begin{array}{l}\text { and see my students as much since they usually turn off their cameras } \\
\text { to save data }\end{array}$ \\
\hline Informant 7 & *Internet Connectivity *Technical difficulties *Lack of gadgets or \\
& technological resources of both students and teacher *Students are \\
& passive and lacks motivation *Difficulty in engaging and motivating \\
& the students to collaborate or participate, especially during group \\
& activities * It is hard to evaluate and keep track students' progress * \\
& Lack of interaction and isolation (teacher to students/students- \\
& students) *LMS platform imperfections/errors *Increase number of \\
& Students cheating during their major examination or even with their \\
& quizzes, seatwork, activities, and more. \\
\hline Informant $\mathbf{8}$ & Consistent internet is most important in an online class. Students \\
& who do not have one will have difficulty following the lessons. \\
\hline Informant $\mathbf{9}$ & Internet connection and modalities. \\
\hline Informant $\mathbf{1 0}$ & Student's attention and connectivity. \\
\hline Informant $\mathbf{1 1}$ & As of now, the internet connectivity and technical difficulties \\
\hline Informant $\mathbf{1 2}$ & some of our students do not have gadgets /net connections \\
\hline
\end{tabular}

\section{CONCLUSION}

This study focused on the Secondary High School Science teachers affiliated with an institution offering online classes. This narrative study was conducted to know the teaching techniques the respondent teachers are implementing, how they can say that these techniques are effective in an online session, and the obstacles these teachers are facing along with these techniques they are using in their everyday lives endeavors. It was revealed that most, if not all the teachers involved in this study, use different strategies to deliver their instructions online. These teachers often include the deductive method in their methods in teaching techniques. Meanwhile, educators test their teaching techniques and efficiency in online classes by looking at the students' assessment results. Lastly, it was mentioned by the respondents that the biggest hindrance they are usually encountering in online classes and in implementing their preferred teaching technique. It can be concluded that there is no effective teaching technique for every teacher, especially in these trying times of having interactive discussions online. The overwhelming connectivity issue that is slowly decimating the educational system is also something to be pondered by those in authority since everyone is still trying to adapt to this system. In line with the results gathered, the researcher of this study would like to make the following recommendations:

1. For the curriculum implementers and teachers, select the appropriate teaching techniques they deemed necessary for every topic, considering the learners' competencies that need to be met.

2. For the government in charge of the internet regulation in the country, internet access and speed have not improved, knowing that this is essential in carrying out these types of learning activities until the foreseeable future. The least you can do is ensure that the service providers provide the services every sector needs.

\section{Funding and Conflicts of Interest:}

The authors declare that there is no funding and conflicts of interest for this article.

\section{REFERENCES}

Arrieta, G.S., Dancel, J.C., \& Agbisit, M.J.P. (2020) Teaching Science in the New normal: Understanding the experiences of Junior High school Science teachers. Journal Pendidikan $M I P A, 21(2)$. Retrieved from https://www.researchgate.net/publication/347487636 Teaching Science in The New No rmal Understanding The Experiences of Junior High School Science Teachers 
Babincakova, M. \& Bernard, P. (2020). Online Experimentation during COVID-19 Secondary School Closures: Teaching Methods and Student Perceptions. Journal of Chemical Education, 97(9). https://doi.org/10.1021/acs.jchemed.0c00748

Bybee, R.W., Taylor, J.A. \& Gardner, A. (2006). The BSCS 5E Instructional Model: Origins, Effectiveness, and Applications. Retrieved from https://www.researchgate.net/publication/242363914 The BSCS 5E Instructional Mode 1 Origins Effectiveness and Applications

De Vera, J.L. (2020). Challenges and Teacher Resilience: The New Normal Classroom Instruction Using Social Media in Philippine Context. Retrieved from https://www.researchgate.net/publication/344467152 CHAPTER-

11 Challenges and Teacher Resilience The New Normal Classroom Instruction Using So cial Media in Philippine Context

Gamiao, J. (2020, July 28). Innovative teaching methods in the new normal. The Manila Times. Retrieved from https://www.manilatimes.net/

Harvard University. Best practices: online pedagogy. https://teachremotely.harvard.edu/bestpractices?fbclid=IwAR310eC8DIXq5miirIkcKj4Km9GpKQ91adVts9Bx6pTaL3aFVEsZSrfGw $\underline{70}$

Hew, K.F., Jia, C., Gonda, D.E., \& Bai, S. (2020). Transitioning to the "new normal" of learning in unpredictable times: pedagogical practices and learning performance in fully online flipped classrooms. International Journal of Educational Technology in Higher Education. 17(57). Retrieved from https://educationaltechnologyjournal.springeropen.com/articles/10.1186/s41239-020$\underline{00234-X}$

Konig, J., Biela, D.J., \& Glutsch, N. (2020). Adapting to online teaching during COVID-19 school closure: teacher education and teacher competence effects among early career teachers in Germany. European Journal of Teacher Education, 43(4). Retrieved from https://www.tandfonline.com/doi/full/10.1080/02619768.2020.1809650

Lagua, B.D. (2020, October 30). Teaching in the new normal. The Manila Times. Retrieved from https://www.manilatimes.net/

Latheef, Z.I. (2020). Synchronous strategies for the "New Normal." Retrieved from https://www.facultyfocus.com/articles/online-education/online-course-delivery-andinstruction/synchronous-strategies-for-the-new-normal/

Manila Standard lifestyle (2020, September 5). Filipino teachers on adjusting to distance learning. Manila Standard. Retrieved from https://manilastandard.net/mobile/article/333348

May, V.L. \&Elkana, M. (2020). Using Human-centered strategies to adapt science lessons for remote learning. Retrieved from https://www.edutopia.org/article/using-human-centeredstrategies-adapt-science-lessons-remotelearning?fbclid=IwAR0qbOKYXQDmGI3wLWJzx2WtfvRJUr1mRqYPEhGEqV3wfTB5piUqzYegH4

Melonchon, L. (2007). Exploring Electronic Landscapes: Technical Communication, Online Learning, and Instructor Preparedness. Technical Communication Quarterly, 16(1). http://dx.doi.org/10.1080/10572250709336576

Miller, K.W. (2008) Teaching Science Methods Online: Myths about Inquiry-based Online learning. Science Educator, 17(2). Retrieved from https://files.eric.ed.gov/fulltext/EJ886175.pdf

Oyelekan, O.S., Igbokwe, E.F., \& Olorundare, A.S. (2017). Science Teachers' Utilisation of Innovative Strategies for Teaching Senior School Science in Ilorin, Nigeria. Malaysian Online Journal of Educational Sciences, 5(2). Retrieved from https://files.eric.ed.gov/fulltext/EJ1142454.pdf 
Pokhrel, S. \& Chhetri, R. (2021). A Literature Review on Impact of COVID-19 Pandemic on Teaching and Learning. Higher Education for the future. https://doi.org/10.1177/2347631120983481

Prieto, N.G., Naval, V.C., \& Carey, T.G. (2017). Practical Research 1 (Qualitative) for Senior High School. Quezon City, Philippines: Lorimar Publishing, Inc.

Redmond, P. (2011). From face-to-face teaching to online teaching: Pedagogical transitions. Proceedings Ascilite 2011 Hobart: Full Paper. Retrieved from https://www.researchgate.net/publication/267242941 From face-toface teaching to online teaching Pedagogical transitions?fbclid=IwAR1dE6NZ3eYnnsPZPBy3B2xDZPxm8mJKpW41A2y3UebcqejtlLtFuVIftw

Swan, K., Shen, J., \& Hiltz, S.R. (2008). Assessment and collaboration in online learning. Journal of Asynchronous Learning Network, 10(1). https://doi.org/10.24059/olj.v10i1.1770

Teachthought (2018). 10 innovative learning strategies for modern pedagogy. Retrieved from https://www.teachthought.com/the-future-of-learning/10-innovative-learning-strategiesfor-modern-pedagogy/

The Star (2020, November 15). Learning Strategies for the new normal. Retrieved from https://www.thestar.com.my/news/education/2020/11/15/learning-strategies-for-thenew-normal

Tobias, J. (2021, February 9). What Filipino educators learned from a year of online teaching. The Philippine Star. Retrieved from https://www.philstar.com/

The University of Illinois Springfield. Instructional Strategies for an online course. Retrieved from https://www.uis.edu/ion/resources/tutorials/pedagogy/instructional-strategies-foronlinecourses/?fbclid=IwAR0QncgHkiBMebievMMHjD3DZcUt0jeAn8eULp93Yh9gCyAc6e70$\mathrm{y} 000 \mathrm{Rw}$

Yang, D. (2013). Instructional strategies for teaching Science online. Frontiers in Education Conference. https://doi.org/10.1109/FIE.2013.6685081

Yang, D. (2017). Instructional strategies and course design for teaching statistics online: perspectives from online students. International Journal of STEM Education, 4(34). Retrieved from https://stemeducationjournal.springeropen.com/articles/10.1186/s40594-017-0096-X

Yang, Y. \& Cornelious, L.F. (2005). Preparing Instructors for Quality Online Instruction. Online Journal of Distance Learning Administration, 8(1). Retrieved from https://www.westga.edu/ distance/ojdla/spring81/yang81.htm

Yang, Y. \& Cornelious, L.F. Ensuring quality in online education instruction: What instructors should know? Retrieved from https://files.eric.ed.gov/fulltext/ED484990.pdf 